\title{
Does pragmatism always work?
}

\section{Political objectives of the}

\section{Australian government in North-East Asia}

\section{Rachel West}

Flinders University of South Australia

As with any country, the political objectives of Australian foreign policy are based on Australian national values. Yet, because such values are inherently based on governmental interpretation, political leanings have created legitimate differences in the objectives pursued in Australian foreign policy over time. This article will explore these differences through Australia's position as a Western, liberal democracy located in the Asia-Pacific. This will be done by examining Australia's relations with those countries which represent the convergence of the Asia-Pacific's most significant economic, strategic, and political links - Northeast Asia. ${ }^{1}$ What will be apparent is that, while determined in its resolve, the political objectives pursued by the current Howard government have proved to be both contentious and potentially damaging to Australia's standing in the region.

Differences in the political objectives pursued as part of Australia's foreign policy in the Asia-Pacific have resulted from different understandings of how to reconcile Australia's "history" with its "geography". As a result, this has led to two very distinct policies from the major political parties regarding Australia's engagement of the region, including with those countries of Northeast Asia.

Under previous Labor government, the difference between Australia's history and geography was seen as a barrier to Australia's relationship with countries of the region. The opposite is true, however, under the current Liberal-led government of John Howard: Australia's European history, the American alliance, and its location in Asia together are seen to create a unique strength in advancing Australia's interests, both regionally and on the global stage. Because of this strength, to change Australian values or its politics to converge with those of the region would be a mistake. Rather, the political objectives of foreign policy in Northeast Asia under the Howard government have come to be

\footnotetext{
${ }^{1}$ Northeast Asia is generally understood to encompass China (including Taiwan), Japan, North and South Korea, and the eastern regions of Russia. However, due to the decline in Russia's in regional significance since the end of the Cold War, these eastern regions hold limited significance to Australia's engagement of Northeast Asia. Thus, for the purpose of this article, Northeast Asia refers to China (including Taiwan), Japan, and North and South Korea.
} 
defined by mutual respect: shared interests are promoted, while differences are "managed".

Such mutual respect is crucial to understanding Australia's political relationships in Northeast Asia under the Howard government. While the shared attributes of liberal democracy and the American alliance are regarded as the foundation of Australia's partnerships with Japan and South Korea, it is the management of difference through bilateral dialogues which characterizes Australia's political relationship with China. This pragmatism on the part of the Howard government has seen all three relationships grow in strength.

Yet, divisions between Japan, South Korea, and China themselves mean that little has yet to be achieved in terms of a cohesive, meaningful Northeast Asian political unit. Regionalism has instead had to be advanced through the much broader framework of East Asia, and is being directed by the Association of Southeast Asian Nations (ASEAN). For ASEAN member countries, for whom gesture and symbolism remain crucial elements of regional politics, Australia's lack of willingness to converge with Asian values and ideals has proven contentious: the East Asian Summit process is a case in point. Thus, while Australia has achieved great success in strengthening its bilateral political relationships with the countries of Northeast Asia, its relations with the Northeast Asian region as a whole have first had to be filtered through ASEAN. The Howard government's success at a regional level has therefore been less impressive. Ultimately, success requires a greater degree of foreign policy flexibility, and indeed foreign policy foresight, than this government has been able to provide.

\section{The role of Australian values in foreign policy}

The task of Australian foreign policy makers is to advocate and advance the national interest in a way that is "both effective and in accordance with the values of the Australian people" (Department of Foreign Affairs and Trade 2003, p. vii). This extension of Australian values into foreign relations is achieved through the political objectives of foreign policy. Such responsiveness to, and representation of, Australian values therefore implies certain foreign policy traditions which continue to shape the pursuit of the national interest, regardless of the politics of the government in power. Clearly, these political objectives are informed by Australia's almost unique status as a Western, liberal democracy located in the Asia-Pacific.

As a liberal democracy, the political and economic values that have shaped Australia's institutions and outlook are acknowledged as guiding its approach to international affairs (Department of Foreign Affairs and Trade 2003, p.vii). Working with other liberal democracies in promoting political and economic freedoms is therefore seen as one way of helping to build a more prosperous and secure world (Department of Foreign Affairs and Trade 2003, p.2). Moreover, Australia's immediate political focus is necessarily to the north: the inaugural foreign and trade policy white paper, introduced under the Howard government, concluded that "changing relativities of power and influence of 
East Asia's economic rise" was one of only two major trends with the capability to reshape the international environment (Department of Foreign Affairs and Trade 1997, p. 17-18). ${ }^{2}$

As with every Australian government since World War II, the Howard government also frames Australia's political relationships with Northeast Asia through the prism of its alliance with the United States. While the significance attributed to this special relationship may have fluctuated with changes of government, the Australia-US partnership, as well as the US alliance system more broadly, has continued to influence the way in which Australia interacts politically. Thus, the United States' global reach in international affairs has meant that strengthening Australia's ability to influence and work with the US is essential in advancing Australian national interests (Department of Foreign Affairs and Trade 1997, p.xvi).

However, the Howard government is also responsible for key departures in traditional Australian foreign policy thinking. Under Howard and the Minister for Foreign Affairs, Alexander Downer, the Department of Foreign Affairs and Trade has been active in promoting its "hard-headed" assessment (see, for example, Department of Foreign Affairs and Trade 2003, p. xvi) of the Australian national interest. In particular, while Labor governments have in the past attempted to define Australia as "part of" Asia, the Liberal-led government of Howard and Downer has consistently argued that Australia is "not Asian" and not "part of" Asia (Fitzgerald 1997, p. 38). Thus, while engagement with East Asia continues to be an important feature of Australian foreign policy under Howard, this "does not imply or require modification of other long-standing links and loyalties", (Dalrymple 2003, p. 97) including Australia's alliance with the US.

Dalrymple argues that Labor's identification of Australia as part of Asia was to overcome what was seen as a major obstacle in Australia's engagement with the region: the incompatibility between Australia's "history" and its "geography" (Dalrymple 2003, p. 221). Howard, however, argues that Australia does not need to choose between its history and its geography, because "we have learned not to tie ourselves in knots defining Australia's place in the world with some unyielding and rigid formula" (Howard 2005a). Australia should focus on the strength derived from the "unique intersection" it occupies as a country in the Asian region with a strong European heritage and close links to the United States (Liberal Party 2001, p.8). This interplay between geography and history is not a "zero-sum game" (Department of Foreign Affairs and Trade 2003, p. 4). Nor does it imply a need to choose between East and West, or a need to qualify Australian values in the pursuit of its interests in Asia.

Rejecting the need for Australia to adapt in order to fit in, the Howard government has instead argued that Australian security and prosperity in Northeast Asia (and in Asia generally) requires a "balance of principle and

${ }^{2}$ The other trend was globalisation. Both were regarded as having the ability to profoundly influence Australia's foreign and trade policy over the next fifteen years. 
pragmatism" (Howard 2005a). Engagement with the region therefore proceeds not just on the basis that the values and traditions of Australian society are taken as a given, (Department of Foreign Affairs and Trade 2003, p.5) but also involves mutual respect and acknowledgement of differences. Under Howard, Australian political relationships in Northeast Asia are built upon common interests, in particular through emphasizing important economic, diplomatic, and security relationships (Department of Foreign Affairs and Trade 2003, p. $x v)$.

While recognizing the role of national values in foreign policy, this balance of principle and pragmatism has resulted in the Howard government engaging principally with "those countries with which [Australia's] primary strategic and economic interests reside" (Howard 2005a). By endorsing political objectives that are "somewhat values-based", the government is therefore promoting a sense of "practicality" in its approach to Northeast Asia (Fallows 2006, p.10).

This pragmatism has also resulted in a focus on strengthening of Australia's bilateral relationships under the Howard government, rather than "ambitious initiatives designed to demonstrate regional credentials and capacities" (Dalrymple 2003, p. 144). Such "practical bilateralism" (as it has been termed by Downer) has come to fundamentally define the political objectives pursued as part of Australian foreign policy in Northeast Asia, and is based on identifying common interests and building on them at the bilateral level (Downer 1996) (check quote).

The pragmatism promoted in Australian foreign policy under the Howard government has also come to characterize Australia's approach to the Northeast Asian region as a whole. In 2000, Downer claimed that there two types of regionalism: cultural regionalism, built on common ties of history, mutual cultural identity, and what he described as "emotional links", and practical regionalism, in which "countries which are bound together by geography find practical ways of working together to achieve their mutual objectives" (Downer 2000).

For a country which is "only able to attain, and thus only interested in" practical regionalism (Dalrymple 2003, p. 155), Downer's comments are revealing of the way in which Australia wishes to engage with Asia. Australia wants an East Asian regional architecture that will evolve in an open, transparent, and inclusive manner, and "with the expectation that the US will continue to play a prominent role in bringing prosperity and stability to our region" (Downer 2006a). Significantly, when asked to discuss drivers of regional integration, Downer placed the newly formed "ASEAN+3 East Asia Summit" last on the list, as the only region-wide institution that formally excludes the United States (Downer 2006b). Yet, while significant in their own right, the Asia Pacific Economic Cooperation (APEC) grouping and the ASEAN Regional Forum (ARF) - the two institutions Downer ranked above the East Asia Summit process - are both also regarded by regional countries as institutions which engage "outsiders" with the region (Dalrymple 2003, p. 103). 
Australian distinctions between practical and cultural regionalism, and between Asia-Pacific as opposed to exclusively Asian regional institutions, are a way not only to promote Australia's own involvement in an emerging East Asian sense of regionalism. It is also designed to ensure the continued presence of Australia's great and powerful, the United States.

\section{Australia and Northeast Asia: the political relationship between Australia and Japan}

Australia continues to have no greater friend in Asia than Japan - Australia's largest export market for almost forty years and a "strategic partner for regional peace and prosperity" (Howard 2005a). Yet, in highlighting the practical role national values can play in foreign policy formulation, John Howard has acknowledged that the long-standing close ties and cooperation between Australia and Japan are not only based on strategic and economic capability, but is also due to "shared values of democracy, freedom, [and] the rule of law" (Howard 2002b). With both countries established liberal democracies, Howard has gone so far as to describe the most important aspect of this partnership as "common values and common beliefs and practices” (Howard 2002a).

These shared values are clearly displayed in Australia and Japan's roles as key US allies in the Asia-Pacific. Downer recently used Australia's military cooperation with Japan in Iraq to demonstrate the significance of such values in Australia's political relationship with Japan. Thus, the Iraq collaboration had not only served to highlight "our ever-deepening bilateral relationship" (Downer 2006a), it also highlighted the overall alignment of Australian and Japanese strategic, economic, and political interests (Department of Foreign Affairs and Trade 1997, p. 60).

Japan's pivotal role in deciding how regional institutions emerge and develop in East Asia, as well as the "quality of East Asia's linkages with other parts of the world" (Department of Foreign Affairs and Trade 1997, p. 60), has been to the benefit of Australia. Japan has long been a supporter of Australian involvement in Asian affairs, and in particular has pushed for Australia to be part of an emerging East Asian community (Howard 2002b). Australia's invitation to the inaugural East Asian Summit in late 2005 was largely due to such Japanese support. Together, Japan and Australia have also made it clear that they wish to see East Asian regional architecture evolve in an open, transparent, and inclusive way, and both expect the US to be an integral part of this process (Downer 2006a).

The Howard government has acknowledged the decisive bearing Australia's relationship with Japan has both on Australia's standing in East Asia, and the degree of participation it has in regional affairs (Department of Foreign Affairs and Trade 1997, 60). Politically, as well as economically and strategically, this partnership with Japan remains one of Australia's "most important and mature" relationships anywhere in the world (Downer 2003). 


\section{The political relationship between Australia and South Korea}

The Australian political partnership with South Korea is also one of Australia's most important regional relationships. South Korea is a liberal democracy, a market economy, and a long-standing American ally. These common values and beliefs, like those with Japan, make South Korea a close regional friend of Australia.

Australia's role during the 1950-53 Korean War is also significant, with South Korea still regarding Australia as a long-term friend and ally (Hakjoon 2002, p. 99). Both countries remain committed to peace on the Korean peninsula; that Australia is one of the few countries worldwide with full diplomatic relations with North Korea adds a further dimension to Australia's own political relationship with the South.

Also significant for Australia is South Korea's own developing political relationship with China. Rozman argues that due to Seoul's "superior" relations with both China and Japan, South Korea increasingly holds a critical position in the politics of Northeast Asia (Rozman 2004, p.373). Despite its smaller population and economy, therefore, South Korea has come to have a "disproportionate say" in the Northeast Asian region (Rozman 2004, p.372). Like Japan, South Korea's critical role in emerging East Asian regional institutions makes Australia's political relationship with this country increasingly important to the pursuit of the Australian national interest.

\section{The political relationship between Australia and China}

Unlike South Korea and Japan, the Australia-China partnership is defined primarily by the political differences between the two countries, as well as their economic complementarities, rather than any political values they share. With the Howard government identifying China's growing regional weight as the single most important trend in the region (Department of Foreign Affairs and Trade 2003, p.22), Australia has worked with China to build a common understanding of how to manage relations in a way that makes the most of shared values, whilst acknowledging differences (Department of Foreign Affairs and Trade 2003, p.79).

Central to this understanding has been the use of bilateral dialogues, which are seen as offering not only the best prospects to manage differences in a practical way, but also to "maximize shared economic interests and advance Australia's political and strategic objectives" (Department of Foreign Affairs and Trade 1997, p.79). In particular, Sino-Australian relations improved dramatically after Australia established a bilateral human rights dialogue in 1997, in return for Australia dropping support for annual moves in the UN condemning China over human rights abuses (Smith 2003, p.2). At the time, the Howard government maintained that a bilateral human rights dialogue would improve relations, while also giving Australia greater influence in China itself (Smith 2003, p.2). Though the government acknowledges that progress has been slow, it believes that this is preferable to the alternative - public 
condemnation of China - which would generate no progress at all and could well have a corrosive impact on the bilateral relationship over time (Department of Foreign Affairs and Trade 2006).

China's increasingly important role in East Asian regional developments is also significant in Australia's political relationship with this country. Australia has welcomed China's regional involvement, in particular with ASEAN and the ASEAN+3 process (Department of Foreign Affairs and Trade 2005, p.17). Beijing is also playing a growing diplomatic role on such regional issues as North Korea's nuclear program and economic cooperation. Australia has, however, continued to remind China that regional structure should be open and inclusive, and that "continuing strong political, strategic, and economic engagement in the region by the United States is vital to regional security and prosperity" (Department of Foreign Affairs and Trade 2005, p.17)

Clearly, the type of interaction Australia enjoys with South Korea and Japan is not something its shares in its political relationship with China. Howard has acknowledged that there is instead a "strong streak of pragmatism" in his country's relationship with China (Tucker 2006). Australia's One-China policy is therefore frequently restated as a key element on foreign policy, while Australia supports unofficial contacts with Taiwan only to promote economic and trade interests (Department of Foreign Affairs and Trade 2006). As Beijing's diplomatic clout continues to increase, it is difficult to imagine that Australia's approach to be anything but pragmatic.

\section{Australia and the Northeast Asian region}

While Australia works hard to maintain its strong bilateral political relationships with Japan, China, and South Korea, it also confronts the increasingly complex challenges that arise in Northeast Asia as a region. In particular, deteriorating diplomatic relations between China and Japan are presenting a clear strategic risk for the wider region. Irritants range from growing competition over regional resources and the long-running dispute over prime ministerial visits to the Yasukuni Shrine in Japan, to China's rising nationalism and concerns over the future role of the Japanese military. Moreover, this mutual distrust is escalating at a time of deepening economic interdependence and regional integration (Dupont 2005).

As the region's two obvious leaders, good relations between China and Japan are crucial to stability and prosperity throughout East Asia, and thus intrinsically tied to Australia's own national interests. Because of Australia's strong political and economic ties with each power, Dupont argues that Australia has the ability to do more to ameliorate tensions between the two countries and the long-term security risk they present (Dupont 2005). Although the Howard government is keen to see the Sino-Japanese relationship strengthen and gain a positive focus, up till now, however, Howard has declined to offer "gratuitous advice", arguing that he would not appreciate such advice from either country concerning a bilateral relationship between Australia and another country (Howard 2005b). 
Deepening Sino-Japanese mistrust highlights the continuing division throughout Northeast Asia, along with the lack of an adequate framework to deal with such tensions. It also serves to spotlight the Australian government's broader strategy in Northeast Asia of balancing relations with Japan, China, and South Korea, whilst avoiding being drawn into such regional flashpoints as the Korean peninsula and Taiwan (Jones and Benventui 2006, p.116).

\section{The politics of the region}

An emergent sense of East Asian regionalism is, however, providing hope for future regional collaboration, as well as a potentially active role for Australia in this process. ASEAN +3 links the ten ASEAN states with those of Northeast Asia, creating an opportunity to discuss issues of importance to East Asia, and to forge a deeper sense of common identity (Dalrymple 2003, p.146). While APEC and the ARF's ineffectiveness through the Asian financial crisis of 1997/98 saw their regional significance decline, ASEAN+3 began to be seen as the new focus for regional dynamics in East Asia. Significantly, the enthusiasm shown by the countries of Northeast Asia for the ASEAN+3 process has lead to suggestions that is the growing ties between China, Japan, and South Korea, with only a weak presence of ASEAN, that really matter (Rozman 2004, p.374). Offering a new venue, minus the US, to bring together the countries of Northeast Asia, by 2001 the ' 3 ' had "upgraded an informal breakfast chat into their own annual summit” (Rozman 2004, p.377).

Regional countries' affinity with, and commitment to, the concept of East Asia was clearly demonstrated with the launch of the East Asian Summit in 2005. Seen as "having the potential to evolve into the principal economic and political decision-making body for East Asia" (Kelly 2005), a number of Asian states, led by Japan, canvassed Australia's attendance at the inaugural Summit.

While the Howard government was seeking closer links to regional groups and institutions, a major point of contention developed between Australia and the region over ASEAN's Treaty of Amity and Cooperation (TAC) being set as the effective price of admission. A key document of the Southeast Asian group, the ASEAN Treaty obliges member countries to uphold the principles of sovereignty, territorial integrity, non-interference in the internal affairs of others, and the peaceful settlement of disputes. For Howard, such principles represented "a mind-set that we've really all moved on from" (Kelly 2005). The TAC was also deemed inconsistent with Australia's obligations under the ANZUS alliance with the US, despite the fact that fellow American allies Japan and South Korea had already signed the Treaty.

When it became obvious that Australia would not be invited to attend the inaugural East Asian Summit because of its refusal to sign the Treaty, it was clear that the Howard government had "misread the role of the Treaty, the mood of the region, and, possibly, the importance of Australia's participation in the Summit process" (Kelly 2005). Recognizing the opportunity almost lost, 
Howard eventually signed the Treaty, securing Australia a foundation seat at the Summit, and hopefully the first step of a budding East Asian regional process.

Australia's efforts to gain a meaningful role in East Asian institutions demonstrates that it is in the area of cultural regionalism "that the grounds for the rejection of Australia's overtures are to be found" (Dalrymple 2003, p.156). The formation and evolution of regional institutions like ASEAN +3 and the East Asian Summit have clearly been influenced by the "emotional links" of cultural regionalism, as demonstrated by the significance attributed to ASEAN's TAC. Ultimately, it is these links which have revealed the Howard government's inability to show policy flexibility, due to its clear preference for pragmatism and bilateralism in its engagement with East Asia. Paul Kelly argues that the furore surrounding Australia's eventual invitation to the East Asia Summit exposes the myths underpinning Howard's Asian diplomacy - firstly, that "gesture, symbolism and cultural signals" are not critical to Australia's acceptance into the region, and, secondly, "that Australia can largely dictate the terms of its engagement" (Kelly 2005).

The announcement of an ASEAN-sponsored East Asian Summit "crystallized Australia's ongoing dilemma about the amorphous character of the region, the uncertainty this breeds," and the policy response best able to address it (Jones and Benvenuti 2006, p.117). In doing so, the East Asian Summit "revealed the diplomatic limitations in Howard's pragmatism and its propensity to disparage regional architecture" (Jones and Benvenuti 2006, p.117). Indeed, what this experience has highlighted is that fact that, for Australia to play an active role in an ASEAN-led East Asian regionalism, Australia must do most of the adapting.

\section{Howard's foreign policy sophistication?}

Regionalism provides a form of organization to deal with regional problems that countries are unable to, or lack the resources to do so (He 2004, p.119). Presently, any sense of Northeast Asian regionalism is wrapped up in the broader concept of East Asia; Northeast Asia remains too divided to form an organization based solely on the core countries of Japan, China, the two Koreas, and Taiwan (Rozman 2003). Growing economic interdependence between all states (with the exception of North Korea) means that the potential for regionalization in Northeast Asia remains. However, currently this process is occurring principally through the ASEAN-sponsored East Asian Summit process. While Australia's need to 'adapt' to win acceptance in East Asia is primarily due to ASEAN's formative role in the East Asian Summit's evolution, it is a modification Australia needs to make nevertheless. For Australia to be a part of this process, therefore, it needs to accommodate the need in Southeast Asia for greater convergence from Australia.

While the Howard government's pragmatism may have proved unsuccessful in its quest for active engagement in East Asia, the opposite has been true in Northeast Asia itself. Australia now has strong, mature political ties with all of the core countries of Northeast Asia, and this has largely been because of the 
pragmatic use of values in Australia foreign policy. While it has been practical to put to one side the difficult issues attendant in Australia's relationship with China, the citing of democratic values, free market enterprise, and the American alliance has also been because of a 'hard-headed' assessment of Australia's political relationships with South Korea and Japan. Australia promotes these shared values with Japan and South Korea because Australia's political relationship with each helps to advance the national interest. Paradoxically, Australia manages the differences over those same values in its partnership with China for the very same reason. Howard's focus on bilateral relations is well suited to the pragmatism that runs deep in Australian foreign policy under a Liberal-led government.

Yet, this focus also denies the advantages offered by an emerging East Asian regional process that has evolved from an ASEAN foundation. Howard's pragmatism and its effective dismissal of 'regional initiatives' means that Australian foreign policy lacks the flexibility it needs to interact adequately with an ASEAN-sponsored East Asian process, where symbolism and gestures are still very much an important part of the political process. For the countries of East Asia, and for many Australians, the Howard leadership has been caught out by the intricacies and idiosyncrasies of regional engagement.

\section{References}

Dalrymple, R. 2003, Continental Drift, Australia's Search for a Regional Identity, Ashgate, Aldershot, Hampshire.

Department of Foreign Affairs and Trade 1997, In the National Interest, Australia's Foreign and Trade Policy White Paper, Commonwealth of Australia, Canberra.

Department of Foreign Affairs and Trade 2003, Advancing the National Interest: Australia's Foreign and Trade Policy White Paper, Commonwealth of Australia, Canberra.

Department of Foreign Affairs and Trade 2005, Submission to the Inquiry by the Senate Foreign Affairs, Defence and Trade References Committee to: Australia's Relations with China, March, pp. 1-31.

Department of Foreign Affairs and Trade (last updated August 2006), "People's Republic of China Country Brief: Australia-China Relations", available www.dfat.gov.au/geo/china/cb index.html, accessed 13 August 2006.

Downer, A. 1996, "Australia, Northeast Asia, and China: Opportunities in a Changing World", Address to a joint Asia/House/Austcham Luncheon, Hong Kong, 4 July, available www.dfat.gov.au/media/speeches/foreign/1996/hongkong.html, accessed 29 September 2006.

Downer, A. 2000, “Opening Speech”, Asia Leaders' Forum, China, 23 April, available www.dfat.gov.au/media/speeches/foreign/2000/000423 alf.html, accessed 12 August 2006. 
Downer, A. 2003, “Australia and Japan: Shared Interests, a Mature Understanding”, Speech to the National Conference of Australia-Japan Societies, Adelaide, 20 September, available www.foreignminister.gov.au/speeches/2003/030920 australia japan.html, accessed 13 August 2006.

Downer, A. 2006a, “Australia-Japan: A Global Partnership”, Speech to the Japan Press Club, 1 August, available www.dfat.gov.au/media/speeches/2006/060801 japan press club.html, accessed 14 August 2006.

Downer, A. 2006b, “Doorstop Interview”, Kuala Lumpur, 27 July, available www.foreignminister.gov.au/transcripts/2006/060727 dskl 1150cc.html, accessed 14 August 2006.

Dupont, A. 2005, “Regional Tensions Awaken”, Australian Financial Review, 3 March.

Fallows, J. 2006, “In Praise of Hypocrisy: The Role of 'Values' in Foreign Policy”, Lowy Institute Perspectives, May 2006, pp. 1-11.

Fitzgerald, S. 1997, Is Australia an Asian Country?, Allen \& Unwin, St. Leonards.

Hakjoon, K. 2002, "Political and Security Issues Between the Republic of Korea and Australia", Paper presented at the Fourth Australia-Korea Forum, Hobart, 16-18 July, pp. 99-100.

He, B. 2004, "East Asian ideas of regionalism: a normative critique”, Australian Journal of International Affairs, vol. 58, no. 1, March, pp. 105-125.

Howard, J. 2002a, “Joint Press Conference with his Excellency Mr Junichiro Koizumi”, Parliament House, Canberra, 1 May, available www.dfat.gov.au/geo/japan/media/transcript_pm 010302.html, accessed 13 August 2006.

Howard, J. 2002b, “Joint Statement with Prime Minister Junichiro Koizumi, AustraliaJapan Creative Partnership", Media Release, Canberra, 1 May, available www.pm.gov.au/news/media releases/2002/media release $1623 . \mathrm{html}$, accessed 13 August 2006.

Howard, J. 2005a, 'Australia and the World', Address to the Lowy Institute for International Policy, $31 \quad$ March, available www.pm.gov.au/news/speeches/speech1290.html, accessed 1 April 2006.

Howard, J. 2005b, Press Conference, Imperial Hotel, Tokyo, 20 April, available www.pm.gov.au/news/interviews/Interview1338.html, accessed 14 August 2006.

Jones, D. M. and Benvenuti, A. 2006, "Tradition, myth and the dilemma of Australian foreign policy", Australian Journal of International Affairs, vol. 60, no. 1, March, pp. 103-124.

Kelly, P. 2005, “Howard Taught a Lesson in Asia”, The Australian, 27 April. 
Liberal Party 2001, “The Howard Government, Putting Australia's Interests First”, Liberal Party, Canberra, pp.1-16.

Rozman, G. 2004, Northeast Asia's Stunted Regionalism, Cambridge University Press, Cambridge.

Smith, A. 2003, "Banking on a Constructive China: Australia's China Debate", in Asia's China Debate, Special Assessment, December, Asia-Pacific Centre for Security Studies, pp. 1-8.

Tucker, S. 2006, "Engaging China 'an Australian priority': Financial Times Interview with John Howard", Financial Times, 1 March. 